\title{
Framing Race and Poverty
}

\section{Citation}

Wilson, William Julius. 2009. Framing race and poverty. Contexts 8(4): 84.

\section{Published Version}

doi:10.1525/ctx.2009.8.4.84

\section{Permanent link}

http://nrs.harvard.edu/urn-3:HUL.InstRepos:11077570

\section{Terms of Use}

This article was downloaded from Harvard University's DASH repository, and is made available under the terms and conditions applicable to Open Access Policy Articles, as set forth at http:// nrs.harvard.edu/urn-3:HUL.InstRepos:dash.current.terms-of-use\#OAP

\section{Share Your Story}

The Harvard community has made this article openly available.

Please share how this access benefits you. Submit a story.

\section{Accessibility}


framing race and poverty

by william julius Wilson

Contexts 8/4 (Fall 2009): 84

One thing I know is that it's extremely important to discuss how race and poverty are framed in public policy discussions. How we situate social issues in the larger context of society says a lot about our commitment to change.

As rhetorician Robert Asen has pointed out, the political framing of poverty - that is, how politicians formulate arguments about how we as a nation should talk about and address issues of poverty-in the New Deal era was quite different from today.

Back then, the emphasis was on structure-namely, the devastating impact of the economic crisis. Americans clearly recognized that hundreds of thousands of citizens were poor or unemployed, mainly because of a severe and prolonged job shortage. In the public arena today, poverty tends to be discussed in reference to individual initiative. This distinction, Asen says, reveals how larger shifts in society have influenced our understanding of the nature of poverty.

Therefore, we ought to consider the contingency of political frames at particular moments in time. These "deliberative frames" not only orient our debates on public policy, but they can also be shifted through debate. So, just because cultural explanations resonate with policymakers and the public today doesn't mean structural explanations can't resonate with them tomorrow. Shifting political frames, however, and hopefully providing a more balanced discussion, requires parallel efforts among politicians, engaged citizens, and scholars.

In the past l've called for framing issues designed to appeal to broad segments of the population. Key to this, I argued, would be an emphasis on policies that directly benefit all groups, not just people of color. Given American views about poverty and race, I thought, a colorblind agenda would be the most realistic way to generate the broad political support necessary to enact the required legislation. I no longer hold to this view.

The question isn't whether the policy should be race-neutral or universal, the question is whether the policy is framed to facilitate a frank discussion of the problems that ought to be addressed and to generate political support to alleviate them.

In framing public policy, we shouldn't shy away from an explicit discussion of the specific issues of race and poverty. Instead, we should highlight them in our attempt to convince the nation that these problems should be seriously confronted and that there is an urgent need to address them. These issues should be framed such that it generates not only a sense of fairness and justice to combat inequality, but also so people are convinced that our country would be better off if these problems were addressed and eradicated. 
In considering this change of frame, I was drawn to Barack Obama's March 18, 2008, speech on race. His oratory provides a model for the type of framing I have in mind.

Obama spoke to the issue of structure and culture, as well as their interaction. He drew attention to the disparities that exist between the "African-American community and the larger American community today"- disparities that "can be traced to inequalities passed on from an earlier generation that suffered under the brutal legacy of slavery and Jim Crow." He also discussed the lack of economic opportunity among black men, and how "the shame and frustration that came from not being able to provide for one's family contributed to the erosion of black families."

However, Obama didn't stop with structural inequities; he also focused on problematic cultural and behavioral responses to these inequities, including a cycle of violence among black men and a "legacy of defeat" that has been passed on to future generations.

By combining a powerful discussion of structural inequities with an emphasis on personal responsibility, Obama didn't isolate the latter from the former. His speech gave an honest appraisal of structural racial inequality as he called for all Americans to support blacks in their struggle to help themselves. I think this speech could serve as a model for the careful political framing of race and poverty we need to move forward in this country.

William Julius Wilson is in the sociology department and Kennedy School of Government at Harvard University. He is author of More Than Just Race. 